\title{
Performance and Meat Cholesterol Content of Broiler Chickens Fed Pluchea indica L. Leaf Meal Reared under Stress Condition
}

\author{
A. Sudarman*, Sumiati, \& S. H. Solikhah \\ Department of Nutrition and Feed Technology, Faculty of Animal Science, Bogor Agricultural University \\ Jln. Agatis, Kampus IPB Darmaga, Bogor 16680, Indonesia \\ (Received 29-10-2010; accepted 11-02-2011)
}

\begin{abstract}
This experiment was conducted to study the effects of dietary addition Pluchea indica L. leaf meal on performances and meat cholesterol content of broiler. One hundred sixty two DOC CP707 strain were reared for four weeks in high stocking density of $15 \mathrm{birds} / \mathrm{m}^{2}$. The birds were fed experimental diets consisted of R1 (commercial feed + Vitastress), R2 (commercial feed $+2 \% P$. indica leaf meal), R3 (commercial feed $+4 \% P$. indica leaf meal), R4 (commercial feed $+6 \% P$. indica leaf meal), and R5 (commercial feed $+8 \% P$. indica leaf meal). The data obtained were analyzed using analysis of variance (ANOVA) and any significant differences were further tested using least significance difference (LSD) test. The treatment significantly increased $(\mathrm{P}<0.05)$ final body weight, body weight gain, feed and water intake, and decreased $(\mathrm{P}<0.05)$ feed conversion ratio. It is concluded that $P$. indica leaf meal could be added into a diet at the level of $2 \%$. P. indica leaf meal addition at the level of $2 \%$ into a diet is also able to decrease the cholesterol content of broiler meat up to $8 \%$.
\end{abstract}

Key words: Pluchea indica, antistress, stocking density, broiler, cholesterol

\section{INTRODUCTION}

It is well known that the optimum stocking density for obtaining good performance of broiler is 10 broilers/ $\mathrm{m}^{2}$. But, it is often that to get high efficiency land use, broiler reared at density more than that suggested, especially in urban area. This practice also aims to restrict the movement of broiler so that feed can be utilized efficiently. Broiler reared at high densities may experience suffered heat stress especially for those reared at hot region and have been associated with a decrease in body weight, feed intake, and flock uniformity and increased frequencies of tibial dischondroplasia, and exacerbated mortality (Pettit-Riley \& Estevez, 2001; Sanotra et al., 2001; Feddes et al., 2002; Galobart \& Moran, 2005; Beloor et al., 2010).

The farmers usually give commercial synthetic anti-stress to the broiler to overcome stressful condition. This practice is not in accordance with the current trend of increasing consumer demand for organic poultry product and will also increase operational cost and reduce profit of the farmer. Moreover, based on the result of Setiaji \& Sudarman (2005) giving synthetic antistress tended to decrease feed intake and weight gain of broiler. To obtain an alternative cheaper and safer anti-stress Setiaji \& Sudarman (2005) used Pluchea indica

*Corresponding author:

Phone +62 251 8626213; e-mail: a sudarman@yahoo.com
$L$. leaf extract into drinking water in their experiment. The results showed that the addition of $P$. indica $L$. leaf extract had significantly $(\mathrm{P}<0.05)$ affected leucocytes and erythrocytes number, haemoglobin, feed intake, and conversion. They concluded that the extract of $P$. indica $L$. leaf could be used as antistress up to $10 \%$ of drinking water and was better given discontinuously.

Other methods of $P$. indica $L$. leaf utilization as an antistress in broiler is needed to be explored. Therefore, the objective of this experiment was to study the effects of $P$. indica $L$. leaf meal addition into diet as an antistress herb on growth performance of broiler reared at high stocking density. Another objective was to elaborate effect of $P$. indica $L$. leaf meal on cholesterol content of broiler meat. At present time, consumers try to avoid animal products consumption or consume it only in limited amount because of its high cholesterol content. High cholesterol intake from diet can cause health disturbance, such as atherosclerosis leading to heart failure disease. Therefore, it is very important to produce low cholesterol containing animal products. $P$. indica contains active compounds, especially essential oil, which is reported by Konjufca et al. (1997) that the essential oils of garlic can reduce cholesterol content of meat broiler.

\section{MATERIALS AND METHODS}

One hundred sixty two DOC of CP 707 strain were allocated into six experimental diet treatments and reared for four weeks. They were placed in 18 cages of 
$1 \times 0.6 \mathrm{~m}^{2}$ each containing nine birds, equal to stocking density of 15 birds $/ \mathrm{m}^{2}$, as a stressful condition. Sixty watt bulb lamp was hung at $15 \mathrm{~cm}$ above bird's head on each cage as a heater during early life and as an additional heat stressor until the end of experiment.

Diet in mesh form was bought from PT Charoen Pokphand. It contained metabolizable energy (ME) and crude protein for starter period (0-3 weeks) of 3,000 kcal/ $\mathrm{kg}$ and $22 \%$, and finisher (3-4 weeks) of 3,100 kcal $/ \mathrm{kg}$ and $20 \%$. The treatments were R1 (diet + Vitastress) as a control, R2 (diet $+2 \%$ P. indica L. leaf meal), R3 (diet + $4 \% P$. indica $L$. leaf meal), R4 (diet $+6 \% P$. indica $L$. leaf meal), and R5 (diet $+8 \%$ P. indica L. leaf meal). Feed and drinking water were offered ad libitum. P. indica L. leaf meal was prepared by air drying the leaves at room temperature for 48 hours, and then dried in an oven at 60 ${ }^{\circ} \mathrm{C}$ for 24 hours. Dry leaves were then ground and added into experimental diet.

At 3 days of age, birds were vaccinated with ND1 vaccine through eye drops, followed by gumboro and ND2 vaccines through drinking water at $10^{\text {th }}$ and $21^{\text {st }}$ day of age, respectively. An antistress of Vitastress was added to drinking water at first day of arrival on R1 (control) treatment, two days before and after vaccination, weighing the birds and replacing of starter by finisher diet (Table 1).

Experimental design was completely randomized design (CRD) with six treatments and three replicates consisting of nine birds each. Data (weekly feed intake and body weight gain, final body weight, feed conversion ratio (FCR), and daily water intake) were analyzed using ANOVA and any mean differences were further tested using least significant difference (LSD) (Steel \& Torrie, 1980). At the end of rearing period, two birds per treatment were slaughtered for meat cholesterol content analysis. Meat cholesterol content was measured from right leg (composite of two legs of two birds) using Lieberman Burchard method (Kleiner \& Dotti, 1962) and data were analyzed descriptively.

Table 1. Nutrient content of Vitastress

\begin{tabular}{lc}
\hline Nutrient & Amount $/ \mathrm{kg}$ \\
\hline Vitamin A & $6.000 .000 \mathrm{IU}$ \\
Vitamin D3 & $1.200 .000 \mathrm{IU}$ \\
Vitamin E & $2.500 \mathrm{IU}$ \\
Vitamin K3 & $3 \mathrm{~g}$ \\
Vitamin B1 & $2 \mathrm{~g}$ \\
Vitamin B2 & $3 \mathrm{~g}$ \\
Vitamin B6 & $1 \mathrm{~g}$ \\
Vitamin B12 & $2 \mathrm{mg}$ \\
Vitamin C & $20 \mathrm{~g}$ \\
Nicotinic acid & $15 \mathrm{~g}$ \\
Calcium-D-pantotenic & $5 \mathrm{~g}$ \\
Electrolit such as $\mathrm{Na}, \mathrm{K}, \mathrm{Ca}$, and $\mathrm{Mg}$ & $750 \mathrm{~g}$ \\
\hline
\end{tabular}

Source: PT. Medion

\section{RESULTS AND DISCUSSION}

The temperature of cages ranged around $30-35{ }^{\circ} \mathrm{C}$. This range seemed to be the comfort zone for the first week broiler age. Meanwhile, the thermal comfort zone for broiler at age of 2, 3, and 4 weeks are 26, 22, and 20 ${ }^{\circ} \mathrm{C}$, respectively (PoultryHub, 2011).

\section{Feed Intake}

$P$. indica $L$. leaf meal addition into diet significantly $(\mathrm{P}<0.05)$ affected feed intake. Broilers fed $\mathrm{R} 2$ had the highest $(\mathrm{P}<0.05)$ among the treatments, while those fed R1, R3, R4, and R5 had similar feed intake (Table 2).

When heat received is greater than heat loss from animal body, body temperature will increase. When such condition last for long time, it will lead to heat stress followed by decreasing feed intake and daily weight gain, and increasing water intake. Lower feed intake due to heat stress was shown by the results of Abu-Dieyeh (2006) that broiler reared for four weeks (4-8 week age) at ambient temperature of $35{ }^{\circ} \mathrm{C}$ has lower feed intake compared to that reared at $20{ }^{\circ} \mathrm{C}$, i.e., 1,851 g/bird vs. 3,565 g bird, respectively. Higher stocking density resulted in higher ambient temperature surrounding animal (micro-climate) due to heat accumulation produced by metabolism process in each animal body. This would contribute to heat stress, especially when animal reared at warm environment such as in this experiment, i.e., 30$35^{\circ} \mathrm{C}$. Results of Beloor et al. (2010) showed that average daily feed intake was reduced from $114.08 \mathrm{~g}$ /bird (low density group) to $103.2 \mathrm{~g}$ bird (high density group), which represented a $9.5 \%$ decrease in high density stocked birds. In this experiment, stocking density was 15 birds $/ \mathrm{m}^{2}$ and additional heat stressor of 60 watt bulb seemed to cause heat stress to the chicken. However, effect of heat stress on the chicken fed R2 seemed to be not as suffer as that on the chicken fed other diets. It is indicated by the higher $(\mathrm{P}<0.05)$ feed intake of chicken fed R2 compared to the others. The optimum level of essential oil contained in R2 was likely to be major influence on it. According to Chong (2011), P. indica leaf contains $0.09 \%$ of sesquiterpenoids (essential oil of $P$. indica). Thus, it was calculated that R2, R3, R4, and R5 diet contained sesquiterpenoids of $18 \mathrm{ppm}, 36 \mathrm{ppm}, 54$ ppm, and 72 ppm, respectively. The same result was also reported by Lee et al. (2004) that were addition of essential oil (cinnamaldehyde) to the rye diet tended to increase in voluntary feed intake.

There are two reasons may explain the lower feed intake of bird fed diet containing $P$. indica leaf meal more than $2 \%$ (R3, R4, R5): (1) high tannin content of $P$. indica leaf, that is $1.88 \%$ (Rukmiasih et al., 2010), resulted in its rather bitter taste which broiler does not like it, and (2) increasing $P$. indica leaf meal into diet would increase essential oil consumed by the broiler. It is known that essential oil has an effect to increase relaxation of small intestine (Magalhães et al., 2004). Excess intake of essential oil could to cause satiated feeling, so that indirectly may reduce diet consumed. Calculation result showed that intake of $P$. indica leaf meal of R1, R2, R3, R4, and R5 were $0,34,62,94$, and $122 \mathrm{~g}$ /bird, respectively. They are 
Table 2. Growth performances of broiler as affected by Pluchea indica L. leaf meal addition into diet

\begin{tabular}{|c|c|c|c|c|c|}
\hline Treatments & $\begin{array}{l}\text { Feed intake } \\
\text { (g/bird) }\end{array}$ & $\begin{array}{l}\text { Body weight gain } \\
\text { (g/bird/day) }\end{array}$ & $\begin{array}{l}\text { Final body weight } \\
\text { (g/bird) }\end{array}$ & $\begin{array}{c}\text { FCR } \\
\text { (Feed:gain, g/g) }\end{array}$ & $\begin{array}{l}\text { Water intake } \\
\text { (ml/bird) }\end{array}$ \\
\hline R1 & $1561 \pm 19^{\mathrm{b}}$ & $31,4 \pm 2,8^{b}$ & $916 \pm 78^{b}$ & $1,8 \pm 0,2^{\mathrm{b}}$ & $3935 \pm 200^{b}$ \\
\hline $\mathrm{R} 2$ & $1691 \pm 107^{\mathrm{a}}$ & $39,8 \pm 4,1^{\mathrm{a}}$ & $1152 \pm 115^{\mathrm{a}}$ & $1,5 \pm 0,2^{\mathrm{c}}$ & $4617 \pm 504^{\mathrm{a}}$ \\
\hline R3 & $1550 \pm 16^{\mathrm{b}}$ & $27,9 \pm 0,8^{\mathrm{bc}}$ & $819 \pm 21^{b c}$ & $2,0 \pm 0,1^{\mathrm{ab}}$ & $3984 \pm 52^{b}$ \\
\hline $\mathrm{R} 4$ & $1562 \pm 21^{\mathrm{b}}$ & $28,0 \pm 0,6^{\mathrm{bc}}$ & $822 \pm 21^{b c}$ & $2,0 \pm 0,1^{\mathrm{ab}}$ & $4298 \pm 341^{\mathrm{ab}}$ \\
\hline R5 & $1527 \pm 35^{\mathrm{b}}$ & $25,3 \pm 1,1^{\mathrm{c}}$ & $745 \pm 30^{c}$ & $2,2 \pm 0,1^{\mathrm{a}}$ & $3960 \pm 137^{b}$ \\
\hline
\end{tabular}

Means in the same column with different superscript differ significantly $(\mathrm{P}<0.05)$. R1 $=$ diet + Vitastress, as control; R2 $=$ diet $+2 \% P$. indica $\mathrm{L}$. leaf meal, $\mathrm{R} 3=$ diet $+4 \%$ P. indica $\mathrm{L}$. leaf meal; R4= diet $+6 \%$ P. indica $\mathrm{L}$. leaf meal; R5= diet $+8 \%$ P. indica $\mathrm{L}$. leaf meal.

equal to intake of sesquiterpenoids of $0.0,0.6,2.2,5.1$, and $8.8 \mathrm{mg}$ bird for R1, R2, R3, R4, and R5, respectively.

Our previous results (Setiaji \& Sudarman, 2005) showed that broilers reared for 5 weeks given $5 \%$ or $10 \%$ pluchea extract into drinking water either continuously or discontinuously had lower feed intake and weight gain compared to those of the control. While result of this experiment showed that addition of pluchea leaf meal of $2 \%$ into diet gave feed intake and weight gain higher than those of the control. It may indicate that giving pluchea leaf meal into diet is better than giving pluchea leaf extract into drinking water.

\section{Body Weight Gain and Final Body Weight}

$P$. indica leaf meal addition into diet significantly $(\mathrm{P}<0.05)$ affected body weight gain of broiler. Broilers fed R2 had the highest $(\mathrm{P} \varangle 0.05)$ body weight gain compared to those fed other experimental diets (Table 2). Body weight gain of broiler fed R5 was lower $(\mathrm{P} \varangle 0.05)$ than that of control group but not different from that of R3 and R4 groups.

$P$. indica leaf meal addition into diet significantly $(\mathrm{P}<0.05)$ affected final body weight of broiler. Final body weight is an accumulation of body weight gain, therefore data of final body weight and that of body weight gain had similar pattern (Table 2). $P$. indica leaf meal addition at level of $2 \%$ (R2) into diet significantly $(\mathrm{P}<0.05)$ resulted in the highest final body weight $(1152$ g/bird), followed by that of those fed R1 (916 g/ekor), R4 (822 g/ekor), R3 (819 g/ekor), and R5 (745 g/ekor). P. indica leaf meal addition at level of $4 \%$ and $6 \%$ resulted in final body weight similar to that of control group.

Effect of high stocking density exarcebated by high environmental temperature can produce lower final body weight. Sekeroglu et al. (2011) reported that broiler reared for six weeks had final body weight of 2,256 g bird at stocking density of 17 birds $/ \mathrm{m}^{2}$ compared to that of 2,420 g bird at stocking density of 9 birds $/ \mathrm{m}^{2}$. Body weight gain has strong correlation with final body weight. In this experiment, broiler fed R2 having the highest body weight gain (39,8 g/bird/day) had also the highest final body weight ( $1152 \mathrm{~g} /$ bird $)$, which is directly affected by their highest feed intake. Addition of $P$. indica leaf meal at level of $2 \%$ into diet obviously increased feed intake, but addition of that more than $2 \%$ had no influence.
Heat stress condition due to high environmental temperature and high stocking density reduced performance of broiler. Broilers exposed to $32{ }^{\circ} \mathrm{C}$ showed nitrogen excretion greater than those reared at $22{ }^{\circ} \mathrm{C}$ (Faria Filho et al., 2007) indicating that stress has been shown to reduce the protein digestibility of broilers. Subsequently, protein availability for formation of new cell of tissue is limited. Effect of essential oil addition into diet on high body weight gain was also reported by other researcher (Lee et al., 2004). Essential oil was also reported to have bactericidal activities on harmful bacteria (Friedman et al., 2002), so that the process of digestion and absorption was not disturbed. However, when intake of essential oil is in excess, such as in this experiment at level of $4 \%$ (R3), $6 \%$ (R4), and $8 \%$ (R5) of $P$. indica leaf meal addition, it depressed feed intake and consequently reduced body weight gain and final body weight.

Flavonoid contained in P. indica leaf was predicted to have antimicrobial activity, as that in Tagetes mendocina Phil. (Lima et al., 2009) which is able to kill pathogenic microbe so that the population of beneficial microbe become optimum in digestive tract. However, intake of flavonoid in excess is not beneficial since fenol residue of flavonoid can interact with protein or digestive enzyme to form covalent bond resulted in the availability of protein for growth became limited (Blair, 2008). This is possibly occurred at broiler groups of R3, R4, and R5 which was given $P$. indica leaf meal at $4 \%, 6 \%$, and $8 \%$, respectively.

\section{Feed Conversion}

Feed conversion ratio (FCR) is affected by many factors, such as environmental temperature, genetics, nutrient content of feed, and disease. Heat stress experiencing poultry due to high ambient temperature resulted in high FCR (Al-Batshan, 2002). P. indica leaf meal addition into diet significantly $(\mathrm{P}<0.05)$ affected feed conversion ratio (Table 2). Broiler in $\mathrm{R} 2$ group, fed diet containing $P$. indica leaf meal at level of $2 \%$, resulted in the lowest $(\mathrm{P}<0.05)$ feed conversion ratio among other groups. Though, feed intake of R2 group broiler was high, but their body weight gain was also far higher than those of other groups. Broiler fed a diet containing $P$. indica leaf meal at level of $8 \%$ (R5) was higher $(\mathrm{P} \varangle 0.05)$ 
than that of control but not significantly different from that of R3 and R4.

The lowest feed conversion value of R2 group may indicated that the diet they fed could be digested, absorbed, and utilized by the body better than other diets, i.e., R1, R3, R4, and R5. This might due to the positive role of active substances contained in $P$. indica leaf, such as essential oil that has an effect to increase protein digestibility and weight gain (Lee et al., 2004; Faria Filho et al., 2007), and flavonoid that has an effect of antimicrobial activity. However, in excess intake of such active substances reduced feed utilization efficiency so that feed conversion value increased. This was occurred in the broilers fed diet R3, R4, and R5.

\section{Water Intake}

$P$. indica leaf meal addition into diet significantly $(\mathrm{P}<0.05)$ affected water intake. Broiler fed diet containing $2 \%$ P. indica leaf meal (R2) had higher $(\mathrm{P} \varangle 0.05)$ water intake compared to that of those fed R1, R3, and R5 but not different from that of those fed R4 (Table 2).

The water intake in this experiment ranged from 3,862 $\mathrm{ml}$ bird upto 4,617 $\mathrm{ml}$ bird. The higher water intake was required by animal for thermoregulatory process, in this study the broilers were reared at suffered heat stress condition, i.e., in high stocking density and high ambient temperature by providing a 60 watt bulb lamp for each cage. This result was supported by Feddes et al. (2002) who reported that water intake of broiler reared for six weeks increased from 5,093 ml bird for stocking density of 11.9 birds $/ \mathrm{m} 2$ to $5,420 \mathrm{ml}$ bird for stocking density of 17.9 birds $/ \mathrm{m}^{2}$. Water intake besides mainly is affected by environmental temperature is also affected by feed intake. The higher feed intake, the higher water intake of the broiler. The correlation between feed and water intake in this study was strong as indicated by their high correlation coefficient ( $\mathrm{r}$ ) of 0.895 .

Water : feed intake ratio in this study were 2.52, 2.73, 2.57, 2.75, and 2.59 for R1, R2, R3, R4, and R5, respectively, indicating there is a tendency to increase water intake with the addition of $P$. indica leaf meal into diet. Water is required, besides for thermoregulatory purpose, also for helping digestion process and absorption of nutrients, transporting nutrients to all tissues cell and carrying waste products out of the body. The values of water : feed intake ratio in this study were higher than that reported by Feddes et al. (2002) for broiler reared for 39 days, i.e., 1.66 and 1.81 for stocking density of 14.3 birds $/ \mathrm{m}^{2}$ and 23.8 birds $/ \mathrm{m}^{2}$, respectively. This discrepancy is due to broilers in Feddes et al. (2002) study were reared at control environment with ambient temperature of $25.9{ }^{\circ} \mathrm{C}$, a comfort temperature for broiler. In contrast, broilers in this study were reared at heat stress condition.

\section{Cholesterol Content of Meat}

Broiler fed diet containing Pluchea indica leaf meal in the diet produced meat with low cholesterol content (Figure 1). The lowest cholesterol content of meat was obtained with the addition of $P$. indica leaf meal at level of $8 \%$ (R5), followed subsequently by R4, R3, R2, and R1 (control), i.e., 1.09, 1.11, 1.13, 1.16, and $1.26 \mathrm{mg} \%$, respectively. Drawing a trend line in Figure 1 resulted in a regression equation of $\mathrm{Y}=1.249 \mathrm{X}^{-0.08}$, with high determination coefficient, $R^{2}=0.976$. This means that the higher the addition level of $P$. indica leaf meal into diet, the lower cholesterol content in meat produced.

Flavonoid contained in $P$. indica leaf has an effect to reduce cholesterol in blood serum through inhibiting micelle formation in small intestine so that decrease intestinal cholesterol absorption (Vermeer et al., 2008). While cholesterol in the body can be eliminated through its conversion by liver into bile acids which is bound to glycine and taurine to form bile salts and secreted to duodenum which is then degraded by microbes in the gut and excreted together with feces, so that body cholesterol content decrease. One of active compounds contained in $P$. indica leaf is essential oil which has an

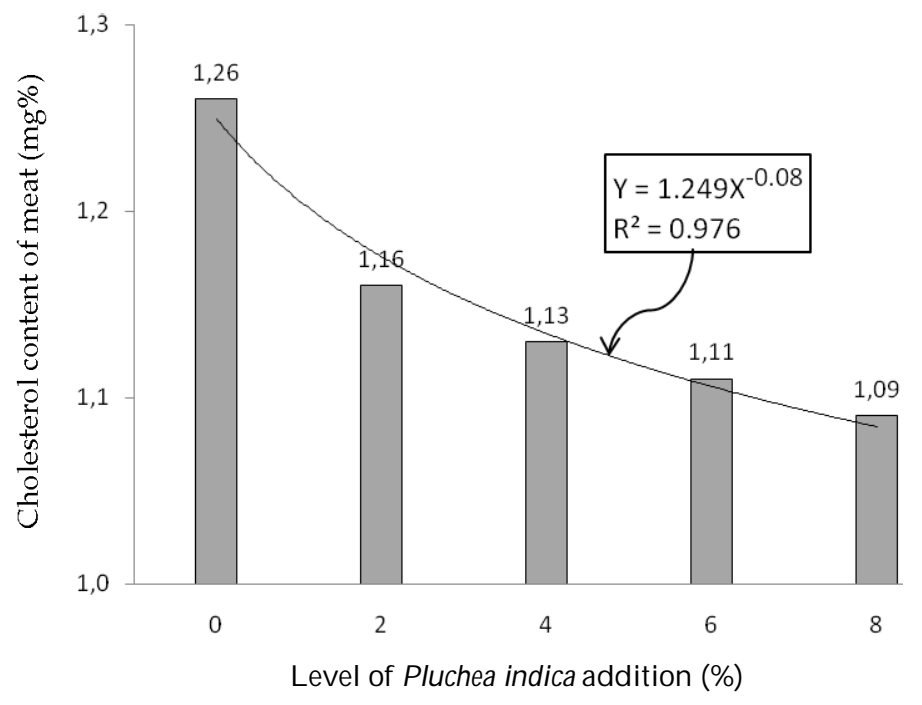

Figure 1. Cholesterol content of broiler meat affected by Pluchea indica leaf meal addition into diet 
effect to increase bile acids secretion (Lin et al., 2008) and may caused the reduction of cholesterol in broiler meat. Results reported by Konjufca et al. (1997) that garlic addition reduced cholesterol content of meat broiler. This due to the activity of the rate-limiting enzyme in cholesterol synthesis, HMG-CoA reductase was suppressed mainly by essential oil contained in garlic.

\section{CONCLUSION}

$P$. indica $L$. leaf meal could be added into a diet as an antistress up to the level of $6 \%$. In order to obtain the highest performance of broiler, however, it is better to be added at the level of $2 \%$. P. indica leaf meal addition at level of $2 \%$ into a diet is also able to decrease the cholesterol content of broiler meat up to $8 \%$.

\section{REFERENCES}

Abu-Dieyeh, Z. H. M. 2006. Effect of high temperature per se on growth performance of broilers. Int. J. Poult. Sci. 5: 19-21.

Al-Batshan, H. A. 2002. Performance and heat toleranceof broilers as affected by genotype and high ambient temperature. Asian-Aust. J. Anim. Sci. 15: 1502-1506.

Blair, R. 2008. Nutrition and Feeding of Organic Poultry. CABI, Wallingford, UK.

Beloor, J., H. K. Kang, Y. J. Kim, V. K. Subramani, I. S. Jang, S. H. Sohn, \& Y. S. Moon. 2010. The effect of stocking density on stress related genes and telomeric length in broiler chickens. Asian-Aust. J. Anim. Sci. 23: 437-443.

Chong, W. K. 2011. Isolation and identification of some rare compounds from essential oils. http://chem.usm.my/ bulletin\%20kimia/kimia usm2.pdf [12-01-2011]

Faria Filho, D. E., D. M. B. Campos, \& K. A. Alfonso-Torers. 2007. Protein levels for heat-exposed broilers: performance, nutrients digestibility, and energy and protein metabolism. Int. J. Poult. Sci. 6: 187-194.

Feddes, J. J. R., E. J. Emmanuel, \& M. J. Zuidhof. 2002. Broiler performance, bodyweight variance, feed and water intake, and carcass quality at different stocking densities. Poult. Sci. 81:774-779.

Friedman, M., P. R. Henika, \& R. E. Mandrell. 2002. Bactericidal activities of plant essential oils and some of their isolated constituents against Campylobacter jejuni, Escherichia coli, Listeria monocytogenes, and Salmonella enteric. J. Food Prot. 65: 1545-1560.

Galobart, J. \& E. T. Moran, Jr. 2005. Influence of stocking density and feed pellet quality on heat stressed broilers from 6 to 8 weeks of age. Int. J. Poult. Sci. 4: 55-59.

Kleiner, I. S. \& L. B. Dotti. 1962. Laboratory Instruction in Biochemistry. $6^{\text {th }}$ ed. The C.V. Mosby Company, New York.
Konjufca, V. H., G. M. Pesti, \& R. I. Bakalli. 1997. Modulation of cholesterol levels in broiler meat by dietary garlic and copper. Poult. Sci. 76:1264-1271.

Lee, K.-W., H. Everts, H. J. Kappert, J. Van Der Kuilen, A. G. Lemmens, M. Frehner, \& A. C. Beynen. 2004. Growth performance, intestinal viscosity, fat digestibility and plasma cholesterol in broiler chickens fed a rye-containing diet without or with essential oil components. Int. J. Poult. Sci. 3: 613-618.

Lima, B., M. B. Agŭero, J. Zygaldo, A. Tapiai, C. Solis, A. R. De Arias, G. Yaluff, S. Zacchino, G. E. Feresin, \& G. S. Hirschman. 2009. Antimicrobial activity of extracts, essential oil and metabolites obtained from Tagetes mendocina. J. Chil. Chem. Soc. 54: 68-72

Lin, L. Y., C. C. Peng, Y. J. Liang, W. T. Yeh, H. E. Wang, T. H. Yu, \& R. Y. Peng. 2008. Alpinia zerumbet potentially elevates high-density lipoprotein cholesterol level in hamsters. J. Agric. Food Chem. 56: 4435-4443.

Magalhães, P. J. C., S. Lahlou, \& J. H. Leal-Cardoso. 2004. Antispasmodic effects of the essential oil of Croton nepetaefolius on guinea-pig ileum: a myogenic activity. Fundam. Clin. Pharmacol. 18: 539-546.

Pettit-Riley, R. \& I. Estevez. 2001. Effects of density on perching behavior of broiler chickens. Appl. Anim. Behav. Sci. 71:127-140.

PoultryHub. 2011. Climate in poultry houses. http://www. poultryhub.org/index.php/ Climate in poultry houses. [17-01-2011].

Puvadolpirod, S. \& J. P. Thaxton. 2000. Model of physiological stress in chickens: 4 . Digestion and Metabolism. Poult. Sci. 79:383-390.

Rukmiasih, P. S. Hardjosworo, W. G. Piliang, J. Hermanianto, \& A. Apriyantono. 2010. Performance, chemical quality, and off -odor of duck's meat (Anas plathyrynchos) fed beluntas (Pluchea indica L. Less) containing ration. Med. Pet. 34: 68-75.

Sanotra, G. S., L. G. Lawson, \& K. S. Vestergaard. 2001. Influence of stocking density on tonic immobility, lameness, and tibial dyschondroplasia in broilers. J. Appl. Anim. Welf. Sci. 4:71-87.

Sekeroglu, A., M. Sarica, M. S. Gulay, \& M. Duman. 2011. Effect of stocking density on chick performance, internal organ weights and blood parameters in broilers. Journal of Animal and Veterinary Advances. 10: 246-250

Setiaji, D. \& A. Sudarman. 2005. Ekstrak daun beluntas (Pluchea indica Less.) sebagai obat antistres pada ayam broiler. Med. Pet. 28: 46-51.

Steel, R. G. D. \& J. H. Torrie. 1980. Principles and Procedures of Statistics: A Biometric Approach. McGraw-Hill Book Co., New York.

Vermeer, M. A., T. P. J. Mulder, \& H. O. F. Molhuizen. 2008. Theaflavins from black tea, especially theaflavin-3-gallate, reduce the incorporation of cholesterol into mixed micelles. J. Agric. Food Chem. 56: 12031-12036. 